\title{
THE EIERGING BIFURCATED STANDARD FOR CLASSIFICATIONS BASED ON SEX
}

Until recently, sex-based classifications have been virtually immune from attack under the equal protection clause. In roughly the last decade, however, successful challenges have become increasingly frequent, and currently this clause is a powerful weapon in combating publicly sanctioned sex discrimination. ${ }^{1}$ Unfortunately, the courts which have effected these changes have failed to provide a satisfactory analytical basis for their decisions. The resulting confusion has been greatly increased by the advent of sex-based classifications which are intended to alleviate the effects of past discrimination by granting certain advantages to women today. ${ }^{2}$ In sharp contrast to the severe attitude generally taken towards classifications which disadvantage women, the current judicial tendency is to treat these new "ameliorative"3 practices quite favorably. The disparity in the treatment of these two types of classifications has been accomphshed without any adequate explanation in terms of legal theory. It is the purpose of this Note to provide a full description of this important area of the law and to suggest a comprehensive theoretical model for evaluating classifications based on sex. In so doing, it will be necessary first to describe the currently available standards of review under the equal protection clause. It will next be shown that the courts have traditionally em-

THE FOLLOWING CITATIONS WILL BE USED IN THIS NOTE:

Gunther, The Supreme Court, 1971 Term-Foreword: In Search of Evolving Doctrine on a Changing Court: $A$ Model for a Newer Equal Protection, 86 HARv. L. REv. 1 (1972) Thereinafter cited as Gunther];

Developments in the Law-Equal Protection, 82 HaRv. L. Rev. 1065 (1969) [hereinafter cited as Equal Protection Developments].

1. Discrimination furthered by state action may be reached under the equal protection clause of the fourteenth amendment. When federal action is scrutinized, the appropriate provision is the due process clause of the fifth amendment, which has been held to include protections substantially the same as those afforded by the equal protection clause. See Bolling v. Sharpe, 347 U.S. 497 (1954). See also United States v. Kras, 409 U.S. 434 (1973).

2. This change has been felt most widely, and controversially, in the area of employnent practices, where "affirmative action" programs granting preferences to women have been highly publicized. For a proposed legal analysis of such programs, see notes 122-28 infra and accompanying text.

3. The discussion in this Note will use "ameliorative" in a narrow sense as designating practices which remedy the effects of past discrimination. A comprehensive treatment of ameliorative classifications appears at notes 96-121 infra and accompanying text. 
ployed the lowest of these standards (the rational basis test) to sexbased classifications, with the result that such classifications were almost always upheld. The Note will then discuss the recent transition to a stricter standard of review in sex discrimination cases. It will be argued that the courts are applying sub rosa the highest standard of review (the strict scrutiny test) to classifications which disadvantage women and that the application of this standard is theoretically proper. The discussion will then shift to the recent cases which apparently have restored the rational basis test for ameliorative sex-based classifications. This exemption of amehorative classifications from stricter standards of review will be justified by a basic policy analysis of the equal protection clause. In conclusion, this Note will apply the proposed bifurcated test to several areas in which classifications are commonly made on the basis of sex.

\section{The Three Levels of Review in Equal Protection Cases}

Traditionally, governmental classifications have been upheld against equal protection attack whenever the distinctions have borne an arguable relationship (also called a "rational basis") to a legitimate public objective. ${ }^{4}$ Typically, this objective was not required to have been the dominant motivating force in the minds of the legislators who enacted the provision, nor did it have to be demonstrated that the relationship of the distinction to the objective was grounded in fact. ${ }^{5}$ Often, mere speculation on the part of the court as to the existence of this relationship was enough to sustam the classification. ${ }^{6}$ In recent years, however, the Supreme Court has developed a higher standard of review for classifications based upon either a "suspect" criterion such as race, ${ }^{7}$ or a "fundamental" interest such as the exercise of a constitu-

4. See McGowan v. Maryland, 366 U.S. 420, 426 (1961); Allied Stores, Inc. v. Bowers, 358 U.S. 522 (1959); Williamson v. Lee Optical, Inc., 348 U.S. 483 (1955); Kotch v. Board of River Port Pilot Comm'rs., 330 U.S. 552 (1947); Lindsley v. Natural Carbonic Gas Co., 220 U.S. 61, 78 (1911). See generally Equal Protection Developments 1065 .

5. See generally Equal Protection Developments 1077-87.

6. Equal Protection Developments 1080, citing Goesaert v. Cleary, 335 U.S. 464 (1948) (discussed in text at notes 30-31 infra) and Kotch v. Board of River Port Pilot Comm'rs, 330 U.S. 552 (1947):

Justices Holmes, Brandeis, and Cardozo, who thought the Court should exercise great restraint in reviewing state regulatory statutes, demonstrated considerable imagination in the attribution of conceivable purpose. Historically, the high point of imaginativeness in this area seems to have been attained at the time when Mr. Justice Frankfurter's philosophy of restraint was at its zenith.

7. Examples of suspect classifications, as defined by the Supreme Court, include race, see McLaugblin v. Florida, 379 U.S. 184, 192 (1964), and national ancestry, see Korematsu v, United Ștates, 323 U.S. 214, 216 (1944). Although the Court generally 
tional right. ${ }^{8}$ Such distinctions will be upheld only if they serve a "compelling" state interest; ${ }^{9}$ furthermore, strict scrutiny, to determine whether less restrictive alternatives can be used to achieve the same ends, ${ }^{10}$ will be applied in examining the asserted relationship of the classification to a legislative goal. In marked contrast to the extremely slight risk of judicial disapproval under the traditional standard, ${ }^{11}$ application of the newer test results in almost automatic invalidation. ${ }^{12}$

After examining several recent Supreme Court cases, some commentators liave suggested that a new standard is developing. ${ }^{13}$ Called "rationality scrutiny" by one writer, ${ }^{14}$ this standard purports to apply the traditional rational basis test, yet the legislation is often voided

pays close attention to a regulation which disadvantages the indigent, see, e.g., Harper v. Virginia Bd. of Elections, 383 U.S. 663 (1966); Douglas v. California, 372 U.S. 353 (1963); Griffin v. Illinois, 351 U.S. 12 (1956), it made it clear in San Antonio Independent School Dist. v. Rodriguez, 411 U.S. 1 (1973), that wealth, per se, was not a suspect classification.

8. Fundamental imterests have been defined by the Court to include the right to vote, see Harper v. Virginia Bd. of Elections, 383 U.S. 663, 670 (1966); Reynolds v. Sims, 377 U.S. 533, 561-62 (1964), procreation, see Skinner v. Oklahoma ex rel. Williamson, 316 U.S. 535, 541 (1942), rights with respect to criminal procedure, such as the right to counsel, see Griffin v. Illinois, 351 U.S. 12, 17-19 (1956), and interstate travel, see Shapiro v. Thompson, 394 U.S. 618, 629-31 (1969). In San Antonio Independent School Dist. v. Rodriguez, 411 U.S. 1, 33-34 (1973), the Court said that fundamental rights for equal protection purposes are those "explicitly or inuplicitly guaranteed by the Constitution."

9. For a discussion of what this test involves, see Loving v. Virginia, 388 U.S. 1, 11 (1967).

10. See generally Note, The Less Restrictive Alternative in Constitutional Adjudication: An Analysis, A Justification, and Some Criteria, 27 VAND. L. REv. 971 (1974). If the statute in question can be more closely tailored to fit the evil at which it is ained, then this test will not be met. For cases where the Court found other ineans to achieve the ends desired, see Dunn v. Blumstein, 405 U.S. 330, 348, 351 (1972); Shapiro v. Thompson, 394 U.S. 618, 637 (1969); Carrington v. Rash, 380 U.S. 89, 91 n.3 (1965). Hence, if a statute subject to the strict scrutiny standard is either over or underinclusive and can reasonably be tailored nore exactly to fit its purpose, it will be struck down because there is a less restrictive alternative.

11. See Equal Protection Developments 1087; Note, Sex Discrimination and Equal Protection: Do We Need a Constitutional Amendment?, 84 HaRv. L. Rev. 1499, 1503 (1971).

12. At the time it considered the case, the Supreme Court had never found the compelling state interest test to have been met. However, in Sherbert v. Verner, 374 U.S. 398, 408 (1963), the Court retroactively found a compelling state interest in Braunfeld v. Brown, 366 U.S. 599 (1961).

13. See Gunther; Nowak, Realigning the Standards of Review Under the Equal Protection Guarantee-Prohibited, Neutral, and Permissive Classifications, 62 GEO. L.J. 1071 (1974); Comment, Equal Protection in Transition: An Analysis and a Proposal, 41 Fordiam L. Rev. 605 (1973); Note, New Standard Used for Equal Protection, 53 NeB. L. REv. 312 (1974); cf. Sedler, The Legal Dinensions of Women's Liberation: An Overview, 47 IND. I.J. 419, 451 (1972).

14. Gunther 21. 
where under the old standard it would have been upheld. ${ }^{15}$ The test appears to be means-oriented ${ }^{16}$ in that the Court attempts to make a factual determination of whether the statute furthers a permissible objective rather than merely deferring to legislative judgment. As one noted commentator has observed, "Judicial deference to a broad range of conceivable legislative purposes and to imaginable facts that might justify classifications is strikingly diminished. Judicial tolerance of overinclusive and underinclusive classifications is substantially reduced."17 It must be noted, though, that while the elements of this test have appeared in several recent Supreme Court cases, the Court has never explicitly approved it. ${ }^{18}$

\section{The Traditional Approach: Minimal Scrutiny APPLIEd to Classifications by SEX}

Before $1971,{ }^{19}$ the Supreme Court generally upheld the constitutionality of sex-based classifications under the equal protection clause. Applying the traditional standard of minimal scrutiny, the Court almost invariably ${ }^{20}$ held that the distinction under attack was reasonable in

15. E.g., James v. Strange, 407 U.S. 128 (1972); Weber v. Aetna Cas. \& Sur. Co., 406 U.S. 164 (1972); Eisenstadt v. Baird, 405 U.S. 438 (1972); Berkelman v. San Francisco Unified School Dist., 501 F.2d 1264 (1974); Boraas v. Village of Belle Terte, 476 F.2d 806 (2d Cir. 1973), rev'd, 416 U.S. 1 (1974). However, the validity of this standard has been thrown in doubt by the Supreme Court's reversal of the Second Circuit's decision in Village of Belle Terre v. Boraas, 416 U.S. 1 (1974), rev'g 476 F.2d 806 (2d Cir. 1973), and its analysis of the case on the traditional rational basis test after the Second Circuit had analyzed it by use of the rationality scrutiny test. Furthermore, in light of the Court's insistence on using the traditional test in San Antonio School Dist. v. Rodriguez, 411 U.S. 1 (1973), when, according to proponents of the new test, rationality scrutiny might have been more appropriate, it is unclear whether the Court accepts the new test. See generally Citizens Comm. v. Lindsay, No. 73-2590 at 589 n.5 (2d Cir. Dec. 5, 1974).

16. For criticism of the means-oriented nature of the new test, see Nowak, supra note 13, at 10-12; Comment, "Newer" Equal Protection: The Impact of the Means-Focused Model, 23 Buffalo L. Rev. 665, 678 (1974); Comment, Equal Protection in Transition, supra note 13 , at 635 .

17. Gunther 20.

18. See note 15 supra.

19. The year 1971 is significant because it was then that the Supreme Court decided Reed v. Reed, 404 U.S. 71 (1971), where, for the first time since the aberrational Adkins v. Children's Hosp., 261 U.S. 525 (1923), the Court invalidated a sex-discriminatory statute on equal protection grounds. Although some commentators, e.g., Getman, The Emerging Constitutional Principle of Sexual Equality, 1972 SUP. CT. REv. 157, treated Stanley v. Illinois, 405 U.S. 645 (1972), as an equal protection case striking down a sex-based classification, a close reading of the decision reveals that the result was based on due process grounds and the importance of conceiving and raising children, rather than on equal protection grounds. See Gunther 25.

20. The only exception was Adkins v. Children's Hosp., 261 U.S. 525 (1923). For a discussion of the significance of this case, see note 23 infra. 
view of women's proper role in society ${ }^{21}$ or the need of the female sex for greater protection. ${ }^{22}$ The Court proceeded on the assumption that there were yast differences between women and men, ${ }^{23}$ with the result that the different treatment accorded the sexes could easily be found to have a rational connection to a legitimate public objective.

Typical of the Court's approach under the minimal scrutiny standard were the leading cases of Muller v. Oregon ${ }^{24}$ and Goesaert $v$. Cleary, ${ }^{25}$ both of which mvolyed restrictions on the employment of women. $^{26}$ In Muller, the Supreme Court upheld a statute prescribing a maximum workday for women ${ }^{27}$ as a justifiable method of protecting women from the injurious effects of long working hours. ${ }^{28}$ The Muller

21. E.g., Hoyt v. Florida, 368 U.S. 57, 61-63 (1961).

22. E.g., Muller v. Oregon, 208 U.S. 412 (1908).

23. Though limitations upon personal and contractual rights may be removed by legislation, there is that in her disposition and habits of life which will operate agamst a full assertion of those rights. She will still be where some legislation to protect her seems necessary to secure a real equality of right. Doubtless there are imdividual exceptions, and there are many respects in which she has an advantage over him; but looking at it from the viewpoint of the effort to maintain an independent position in life, she is not upon an equality. Muller v. Oregon, 208 U.S. 412, 422 (1908);

cf. Bradwell v. State, 83 U.S. (16 Wall.) 130, 139 (1872) (Bradley, J., concurring). Indeed, the only Supreme Court case in this period which did not sustain the constitutionality of female protective legislation was Adkins v. Children's Hosp., 261 U.S. 525 (1923), which invalidated a minimum wage law for women on the ground that the differences between the sexes had come "almost, if not quite, to the vanishing point." Id. at 553. Thus, Adkins explicitly recognized that the prior case law im this area was based on the great differences the Court had seen between men and women.

24. 208 U.S. 412 (1908).

25. 335 U.S. 464 (1948).

26. Proponents of much of this legislation maintained that they were motivated solely by concern for woinen's welfare. See Brief for Appellants, Adkins v. Children's Hosp., 261 U.S. 525 (1923); Spritzer, Equal Employment Opportunity Versus Protection for Women: A Public Policy Dilemma, 24 ALA. L. REv. 567 (1972). However, it is clear that the effect of these regulations was to deny women employment opportunities. See Mengelkoch v. Industrial Welfare Comm'n, 442 F.2d 1119 (9th Cir. 1971); Sedler, supra note 13, at 434; Note, Protection, Poverty and the Woman Worker, 5 SUfFolK U.L. REv. 139 (1970). This effect of "protective" legislation for women was not lost upon men. As the president of the International Cigarmakers Union explained in 1879: "We cannot drive the females out of the trade, but we can restrict this daily quota of labor through factory laws." Sedler, supra note 13, at $435 \mathrm{n} .96$, quoting A. HENRY, THE TRADE UNION MOVEMENT 129 (1923).

27. Similar legislation which established a maximum working day for bakers had previously been invalidated on due process grounds. Lochner v. New York, 198 U.S. 45 (1905). Perhaps Lochner can be distinguished on the basis that in Muller the court perceived a threat to women's health from long hours of work, while in Lochner no such threat to bakers' health was perceived.

28. [S] he is so constituted that she will rest upon and look to [her brother] for protection; ... her physical structure and a proper discharge of her maternal functions-having in view not merely her own health, but the well-being of the race-justify legislation to protect her froin the greed as well as the passion of man. 208 U.S. at 422. 
Court did not attempt to disguise its basic rationale that women were properly assigned a lesser role in the scheme of things:

$[\mathrm{H}]$ istory discloses the fact that woman has always been dependent upon man. He established his control at the outset by superior physical strength, and this control in various forms, with diminishing imtensity, has continued to the present .... Differentiated by these matters from the other sex, she is properly placed in a class by herself, and legislation designed for her protection may be sustained, even when like legislation is not necessary for men and could not be sustained. ${ }^{20}$

The Court was not always content to rest its decision on a consideration of women's proper roles; at times, more generalized dangers were seen as possibly arising from the removal of a restriction upon women. For example, in Goesaert the Court sustained a statute forbidding any woman to be a bartender unless she was either the wife or daughter of a male owner of a liquor establishment $t^{30}$ on the ground that such a regulation was a tenable means of protecting the public inorals. According to the Court, "[B]artending by women may, in the allowable legislative judgment, give rise to inoral and social problems against which it may devise preventive measures . . .."31 As recently as 1961 the Court was still applying the minimal scrutiny standard to sexbased classifications. In Hoyt v. Florida ${ }^{32}$ a Florida statute which provided that no woman should be selected for jury service unless she volunteered $^{33}$ was held not to be a demal of equal protection, even though

29. Id. at 421-22.

30. The same question as was presented in Goesaert has sometimes received a different treatment in the lower courts. Brown v. Foley, 158 Fla. 734, 29 So. $2 d 870$ (1947), considered the question a year before the Supreme Court decided Goesaert and concluded that an ordinance which prohibited females from serving any liquor by the drink over a bar was unreasonable. However, the opinion was noteworthy for its lack of reasoning, saying only that "[w]e can see no sound reason in law to sustain the ordinance ...." Id. at 736, 29 So. $2 \mathrm{~d}$ at 871. A more recent decision, Peterson Tavern \& Grill Owners Ass'n v. Borough of Hawthome, 57 N.J. 180, 270 A.2d 628 (1970), reached the same conclusion as Foley in striking down a Goesaert-type ordinance. In Peterson Tavern, the court exphicitly criticized Goesaert. Id. at 631. Sail'er Inn, Inc. v. Kirby, 5 Cal. 3d 1, 485 P.2d 529, 95 Cal. Rptr. 329 (1971), utilized a farther-reaching rationale in holding a statute prohibiting womeu from being bartenders unconstitutional under the equal protection clause. The court in that case found that sex-based classifications were suspect, and hence, subject to strict scrntiny.

31. 335 U.S. at 466 . The Court implied that it was protecting the morality of society as a whole and not merely of women bartenders, thus putting the case into the restrictive category rather than the protective category.

32. 368 U.S. 57 (1961).

33. A statute which completely disallows women from jury service has never been. ruled upon by the Supreme Court, although a lower court held that such an Alabama statute was invalid under the equal protection clause. White v. Crook, 251 F. Supp. 401 (M.D. Ala. 1966). Currently there are no statutes which completely bar women from 
the exemption meant that virtually no women served on juries. ${ }^{34}$ The Court reasoned that women's responsibilities as "the center of home and family life"35 were a sufficient reason for the legislature to excuse them from mandatory jury duty.

Until recently the lower courts have generally followed the lead of Muller, Goesaert, and Hoyt and have sustaimed sex-based classifications on equal protection grounds by applying the permissive rational basis test. $^{36}$ The general insensitivity to sex discrimination ${ }^{37}$ which

jury duty. Johnston \& Knapp, Sex Discrimination By Law: A Study in Judicial Perspective, 46 N.Y.U.L. REV. 675, 716 (1971). The three such state statutes in existeuce at the time of White have since been repealed. See ArA. Code tit. 30, $\$ 21$ (Supp. 1973), amending ALA. CODE tit. 30, § 21 (1958); MISs. CODE ANN. $\$ 13-5-1$ (1972), amending MISs. CODE ANN. $\$ 1762$ (1942); S.C. CODE ANN. $\$ 38-52$ (Supp. 1973), amending S.C. CODE ANN. $\$ 38-52$ (1962). The Mississippi law was further amended in 1974 to specifically state that sex shall not be a barrier to competency for jury duty. Miss. Code ANN. $\$ 13-5-2$ (Supp. 1974).

34. 368 U.S. at 58, 65. For example, in 1957 in one county in Florida there were only ten women jurors out of a hist with 10,000 names on it.

35. Id. at 62; cf. Fay v. New York, 332 U.S. 261, 277-78 (1947); United States v. Caci, 401 F.2d 664, 671 (2d Cir. 1968), cert. denied, 394 U.S. 917 (1969); State v. Alexander, 255 La. 941, 949, 233 So. 2d 891, 894 (1970), rev'd sub nom. Alexander v. Louisiana, 405 U.S. 625 (1972). But see Taylor v. Louisiana, 43 U.S.L.W. 4167 (U.S. Jan. 21, 1975), where the Supreme Court struck down a statute similar to that considered in Hoyt. In Taylor, the Court struck down the legislation on sixth and fourteenth amendment grounds. According to the majority, "We are also persuaded that the fair cross section requiremeut is violated by the systematic exclusion of women . . . ." $I d$. at 4170 . The Court distinguished Hoyt on the ground that it was not a sixth amendment case. Id. at 4171 . However, the validity of this distinction is thrown in doubt when one considers that in Hoyt the statute was challenged by a female defendant convicted of murdering her husband, aud surely the sixth amendment would apply. The Court seemed to recognize this when it stated: "[W] cannot follow the contrary implications of the prior cases, including Hoyt v. Florida. If it was ever the case that women were uuqualified to sit on juries or were so situated that none of them should be required to perforn jury service, that time has long since passed." Id. at $\mathbf{4 1 7 2 .}$

36. The test has beeu used to uphold the draft against equal protection attack, see e.g., United States v. Cook, 311 F. Supp. 618 (W.D. Pa. 1970); United States v. St. Clair, 291 F. Supp. 122 (S.D.N.Y. 1968). It has beeu used to sustain legislation such as the denial to women students of admission to Texas Agricultural and Mechanical University (reasoning that woinen were given the opportunity to attend other comparable state-supported institutions and citing the emphasis on military training at Texas A \& M). Allred v. Heąton, 336 S.W.2d 251 (Tex. Civ. App.), cert. denied, 364 U.S. 517 (1960); Heaton v. Bristol, 317 S.W.2d 86 (Tex. Civ. App. 1958), cert. denied, 359 U.S. 230 (1959). The permissive rational basis test has been used to uphold the rule that a wife has no cause of action in tort for loss of consortium, while according the husband such a right (this rule precluded the possibility of a double recovery should both husband and wife recover for the same loss). Miskunas v. Union Carbide Corp., 399 F.2d 847 (7th Cir. 1968), cert. denied, 393 U.S. 1066 (1969). The courts have upheld a dornitory curfew which applied only to women, basing this result on the idea that the safety of the women students was a reasonable justificatiou for the restriction. Robinson v. Board of Regents, 475 F.2d 707 (6th Cir. 1973). Different periods of minority for men 
typified these mininial scrutiny cases at times approached the bizarre. One state court, for instance, accepted as a valid state objective the desire to protect an "island on the sea of life reserved for man"38 fron the onslaught of female competitors. Taken as a whole, the older cases graphically illustrate the ineffectiveness of the permissive rational basis test in distinguishing classifications which might possibly have a legitiniate basis from those which are due solely to the prejudiced attitudes of the legislators. ${ }^{39}$

\section{The Transition to a'Stricter Standard}

During the late 1960's a change in these attitudes could be detected in the lower courts, ${ }^{40}$ occasioned by changing societal views toward women as exeniplified in new legislation such as the Civil Rights Act of $1964,{ }^{41}$ which forbade employnent discrimination on the basis of sex. During this period it became increasingly clear that the courts were abandoning the traditional approach, but there was considerable uncertainty as to what was to take its place. In 1966 a district court departed fron the historical view of sex-based classifications in White v. Crook $^{42}$ when it invalidated a statute ${ }^{43}$ excluding wonien fronı jury

and women because women "tend generally to mature physically, emotionally and inentally before boys" have been held to justify having a lower age of majority for females, Stanton v. Stanton, 30 Utah 2d 315, 319, 517 P.2d 1010, 1012, cert. granted, 43 U.S.L.W. 3223 (1974).

37. For an article delineating at great length the tenuous nature of some of the relationships between sex-discriminatory statutes and the questionable objectives involved, see Johnston \& Knapp, supra note 33, at 728. As the authors statcd, "Not only are many forms of sex discrimination vulnerable when subjected to 'rigid scrutiny, ' but they cannot even survive a serious application of the 'rational basis' test." Id.

38. State v. Hunter, 208 Ore. 282, 287, 300 P.2d 455, 458 (1956) (upholding conviction of a female for participating in a professional wrestling competition in violation of a state statute).

39. The court in Hunter, see note 38 supra and accompanying text, seems to have based its decision on the prejudicial attitudes of the legislators: "[T]he membership of the legislative assembly which enacted this statute was predominantly masculine. The fact is important in determining what the legislature might have had in mind with respect to this particular statute, in addition to its concern for the public weal." Id. at 287,300 P.2d at 457-58.

40. See, e.g., Mollere v. Southeastern La. College, 304 F. Supp. 826 (E.D. La. 1969); United States ex rel. Robinson v. York, 281 F. Supp. 8 (D. Conn. 1968); Karczewski v. Baltimore \& O.R.R., 274 F. Supp. 169 (N.D. I1l. 1967); White v. Crook, 251 F. Supp. 401 (M.D. Ala. 1966); Cominonwealth v. Daniel, 430 Pa. 642, 243 A.2d 400 (1968).

41. 42 U.S.C. $\$ \$ 2000$ et seq. (1970). See also Frontiero v. Richardson, 411 U.S. 677, 686-88 (1973), for a description of how attitudes are changing.

42. 251 F. Supp. 401 (M.D. Ala. 1966).

43. This statute completely excluded women from serving on juries, as contrasted with Hoyt, where women were excluded unless they volunteered. At the time White 
duty as a denial of equal protection. Clearly this statute could have been upheld on the same basis as was the statute in Hoyt. ${ }^{44}$ However, the court distinguished Hoyt on the ground that in that case women were nat totally excluded from jury service, whereas in White they were. The court went on to declare that in the instant case, the "exclusion of women from jury service . . . is arbitrary,"45 pointing out that jury service was a form of governmental participation. The case did not seen to apply the traditional rational basis test since the complete exclusion of women from jury service arguably furthers the goal of allowing them to fulfill their familial responsibilities, and hence the rational basis test would have been met. ${ }^{46}$ Thus, it was unclear what theory had been used to invalidate the statute.

Two years later, another federal district court, in United States ex rel. Robinson $v$. York, ${ }^{47}$ struck down a statute under which women convicts received indefinite sentences whereas men received shorter fixed sentences. The court rejected the argument that the statute was reasonable under a minimal scrutiny test because women were sentenced to "rehabilitative farms" for indefinite periods long enough to reform then, while men, who supposedly were more incorrigible than wonen, received definite sentences. ${ }^{48}$ Apparently, the court felt that the rational basis standard was mappropriate: "[]t is difficult to find any reason why adult women, as one of the specific groups that coinpose humanity, should have a lesser measure of protection than a racial group." ${ }^{49}$ Since racial classifications are subject to the strict compelling state interest test, ${ }^{50}$ the court seenred to be iniplying that sex-based

was decided only three states completely excluded women. Id. at 408 n.14. Currently no states completely exclude them. See note 33 supra.

44. The statute in Hoyt was upheld on the ground that women's familial responsibilities justified the exclusion. Such responsibilities could also justify a complete exclusion.

45. 251 F. Supp. at 408.

46. See notes 4-6 supra and accompanying text.

47. 281 F. Supp. 8 (D. Conn. 1968).

48. The court explained the reason for adopting the disparate sentencing procedure by saying:

What scant legislative history there is does reveal a belief by those who supported it at a hearing before the Joint Standing Committee on Humane Institutions in February 1917 that the new institution would provide a reformative opportunity not available to women in the prison and jails. That hope was based mostly on features of the proposed farm which are today present in the prison as well or are of little substance, e.g., farm work, a rural location, a name with less stigma attached to it, a woman superintendent. Id. at 14-15 n.5.

Petitioner in this case was sentenced to an indefinite term up to three years, whereas if she had been a man, the maximum sentence for her offense would have been one year and six months.

49. Id. at 14.

50. See note 9 supra and accompanying text. 
classifications should also be subject to such a standard. However, the court also specifically pointed out that the fundamental interest of liberty was at stake, ${ }^{51}$ thereby confusing the issue as to the grounds of the decision-whether it was because a suspect classification or a fundainental interest was involved.

The clearest departure froin the traditional approach was the 1971 case of Sail'er Inn, Inc. v. Kirby ${ }^{52}$ where the California Supreme Court struck down a statute similar to the one upheld in Goesaert ${ }^{33}$ on the ground, inter alia, ${ }^{54}$ that it violated the equal protection clause. The Kirby court was the first which explicitly applied the strict scrutiny standard to a sex-based classification: "The instant case compels the application of the strict scrutiny standard of review, first, because the statute limits the fundamental right of one class of persons to pursue a lawful profession, and, second, because classifications based upon sex should be treated as suspect." ${ }^{\text {"55 }}$ Hence, during the decade after Hoyt the state of the law with respect to sex-based classifications was one of change-although the Supreme Court had not yet deviated from its traditional stance, new attitudes on the part of society, the lower courts, and legislators were putting pressure on the Court to do so.

The 1971 case of Reed $v$. Reed ${ }^{56}$ presented the Supreme Court with an ideal opportunity to re-examine its approach to classifications by sex. In Reed, the Court unaminously invalidated a statute ${ }^{57}$ which gave automatic preference to men over woinen in determining who should administer a decedent's estate. Unfortunately, the Court's explanation of its rationale was far from clear. The decision purported to apply the traditional rational basis test: "The question presented by this case, then, is whether a difference in the sex of competing apphicants for letters of administration bears a rational relationship to a state objective that is sought to be advanced by the operation of [the statute]." ${ }^{58}$ However, the Court summarily rejected the proferred state interests of avoiding intrafamily controversy and improving administra-

51. 281 F. Supp. at 16.

52. 5 Cal. 3d 1, 485 P.2d 529, 95 Cal. Rptr. 329 (1971).

53. Sail'er Inn was not the first case to strike down a Goesaert-type statute. See note 30 supra. However, the previous cases did not explicitly give their grounds for decision in equal protection terms.

54. The court also held that the statute violated the California Constitution and Title VII of the Civil Rights Act of 1964, 42 U.S.C. $\$ \S 2000$ et seq. (1970).

55. $5 \mathrm{Cal} .3 \mathrm{~d}$ at $17,485 \mathrm{P} .2 \mathrm{~d}$ at 539, $95 \mathrm{Cal}$. Rptr. at 339.

56. 404 U.S. 71 (1971).

57. IDAHo GEN. LAwS $\$ 15-314$ (1948): “Of several persons claiming and equally entitled to administer, males must be preferred to females, and relatives to those of the half blood."

58. 404 U.S. at 76. 
tive efficiency. In the Court's view, this was an "arbitrary legislative choice" ${ }^{\text {"9 }}$ and a denial of equal protection. This language was the most confusing aspect of the opinion, since the statute was not "arbitrary" under a traditional rational basis analysis. The Court conceded that the purposes assigned to the statute were legitimate, and it is clearly arguable that these purposes were furthered by the legislation. ${ }^{60}$ The conclusion is inescapable that there was indeed a rational relationship between the classification and a permissible state objective. It would be difficult to iniagine the Court's invalidating a statute which selected administrators by a noncontroversial criterion (for example, giving preference to the candidate whose birthdate came first in the calendar year). Hence, it would seenr that the Court could have reached its decision in Reed only by iniporting some special protection for those disadvantaged by a classification based on sex..$^{01}$

Furthermore, it is apparent that this special protection did not result from using the new rationality scrutiny test, since this intermediate standard would have been inet if the state could have proved that the classification actually resulted in a reduction of intrafamily controversy or an increase in administrative efficiency. ${ }^{62}$ Instead, the defendants were not even given an opportunity to denronstrate such a relationship. ${ }^{63}$ In fact, the Court strongly implied that even if the statute had been shown to be efficacious in ineeting its goals, it still would have been struck down. ${ }^{64}$

\section{In Search of the Reed Principle: WHAT IS THE CURRENT STANDARD?}

The Supreme Court's unanimous opinion in Reed is still the nost

59. Id.

60. Id. at 76-77.

61. See Gunther 34:

[T] he apparent conformity of the Reed opinion to the model [of rationality scrutiny, see notes 19-23 supra and accompanying text] is thrown imto doubt by the holding that the sex criterion was "arbitrary." It is difficult to understand that result without an assumption that some special sensitivity to sex as a classifying factor entered into the analysis .... Even if the requirement be that the means bear a "significant relationship" to the state's purpose, or contribute substantially to its achievement, the test would seem to have been met in Reed. Only by importing some special suspicion of sex-related means from the new equal protection area can the result be made entirely persuasive.

62. The rationality scrutiny test requires that the state bring forth evidence showing that the legislation furthers a valid objective. See text accompanying note 17 supra. See also Berkelman v. San Francisco Unified School Dist., 501 F.2d 1264 (9th Cir. 1974).

63. The question of the efficacy of the statute appears nowhere in the opinion. Instead, after recognizing the legislative goals sought to be achieved by the statute, the Court summarily dismissed the subject with the epithet "arbitrary." See 404 U.S. at 76.

64. See note 10 supra and accompanying text. 
recent definitive pronouncement as to the treatment of classifications which disadvantage women. ${ }^{65}$ For this reason, subsequent decisions in the area have commonly been based on the courts' perceptions of what the Reed Court's analysis actually was. The results have varied as widely as possible, as judges have cited Reed as standing for each of the three currently recognized standards of equal protection review. A typical case which followed Reed im announcing the rational basis test while applymg an unspecified higher standard was Morris v. Michigan State Board of Education, ${ }^{66}$ where the Sixth Circuit invalidated a high school athletic association regulation prohibiting girls from engaging in interscholastic athletic contests with boys, to the extent that the regulation applied to noncontact sports. The court cited Reed for the proposition that "such a classification is subject to scrutiny under the Equal Protection Clause of the Fourteenth Amendment to ascertain whether there is a rational relationship to a valid state purpose." ${ }^{\prime \prime 7}$ However, as in Reed, the decision in Morris seems actually to import some special significance to classifications based on sex, simce the regulation clearly is valid under the traditional rational basis test. The state objective which could be advanced for such a regulation would be that of allowing only those of approximately equal ability to compete against each other. Since the average athletic ability of girls is lower than that of boys, the regulation would further the state objective. The fact that there might be a considerable overlap between the athletic abilities of the two sexes would be of little concern under the traditional test. ${ }^{68}$

In clear contrast to Morris is the same court's decision in Robinson v. Board of Regents, ${ }^{69}$ which used Reed as a precedent for applying

65. The more recent cases of Frontiero v. Richardson, 411 U.S. 677 (1973), and Kahn v. Shevin, 416 U.S. 351 (1974), have not replaced Reed as the most authoritative decision in this area. Frontiero was a plurality opinion, and Kahn dealt with the distinct category of "ameliorative" sex-based classifications. For a discussion of Kahn and its implications, see notes 97-104 infra and accompanying text.

66. 472 F.2d 1207 (6th Cir. 1973).

67. Id. at 1209, citing Reed v. Reed, 404 U.S. 71, $75-76$ (1971).

68. The fact that the results of categorization need not be clinically exact arises clearly from an examination of the leading cases which have applied the minimal scrutiny standard to sex-based classifications. In Muller, there were undoubtedly many women who would not have been injured by long working hours; in Goesaert, there was no showing that all women bartenders were more dangerous to good morals than all male bartenders; and in Hoyt, there were certainly many women who had no family responsibilites. For a discussion of how closely a statute's effect must match the evil at which it is aimed (i.e., over and underinclusiveness) under the traditional, rational basis test, see generally Equal Protection Developments 1084-87. See also Note, supra note 10.

69. 475 F.2d 707 (6th Cir. 1973). Despite the divergence of theories in the two cases, Robinson and Morris were both decided by the Sixth Circuit in the same year. 
the minimal scrutiny standard in its pure form. Robinson rejected a challenge to a state university's dormitory curfew restrictions which were applicable only to women. Citing Reed for the proposition that the permissive rationality test is appropriate in sex discrimination cases, ${ }^{70}$ the court refused to find a violation of the equal protection clause. Since the goal of the restrictions was the safety of women students, ${ }^{71}$ the regulations' presumptive validity was not overcome merely by showing that different sets of rules applied to nien and women. That Robinson represents a retreat froin the heightened scrutiny of Reed and Morris is obvious. The classification in Robinson would appear to be no more reasonable than the ones in the earlier cases when one considers the lack of proof (1) that women who were not subject to dormitory curfews were exposed to more danger than those who were subject to such curfews or (2) that women unprotected by curfews were exposed to more danger than the men who were not so restricted. $^{72}$ Rather, the court seems to have based its decision on unfounded or untested assumptions about women in much the same manner as did the Courts in Muller, Goesaert, and Hoyt.

One recent case has interpreted Reed as an example of the new rationality scrutiny model. In Berkelman v. San Francisco Unified School District ${ }^{73}$ the Ninth Circuit explicitly applied this intermediate standard ${ }^{74}$ in loolding that a selective public high school which applied an admissions quota of equal numbers for each sex violated the equal protection clause where such a policy resulted in higher entrance standards for girls. ${ }^{75}$ According to the court, Reed indicated "that sex classifications are to be tested on the basis of strict rationality, a standard of review requiring the government (state or federal) to produce evidence that the challenged classification furthers the central purpose of the classifier."76 In Berkelman, the admissions policy was invalidated

70. Id. at 710, citing Reed v. Reed, 404 U.S. 71, 75-76 (1971).

71. 475 F.2d at 711 .

72. In other words, there was no showing that the least restrictive alternative was used.

73. 501 F.2d 1264 (9th Cir. 1974).

74. The court applied what it called a "strict rationality" standard and cited Gunther's leading article on rationality scrutiny. Id. at 1269; see Gunther 21.

75. This difference amounted to a 3.50 grade point average on a four-point scale for admission of girls and a 3.25 grade point average for boys. This policy kept 133 girls from being admitted who would liave been admitted if equal criteria liad been used. Since the high school involved was a special college preparatory school which offered significantly more courses and resources than other high schools in the district, this imposed a considerable hardship on those denied admission. Opening Brief for Appellants at 7-8, 24, Berkelinan v. San Francisco Unified School Dist., 501 F.2d 1264 (9th Cir. 1974).

76. 501 F.2d at 1269. 
because the school failed to prove that since boys overtake girls academically in high school and college, ${ }^{77}$ the use of disparate standards actually promoted a legitimate state end of providing a quality education for those who would benefit the nost froin the experience. Presumably, if the school had proved its contention, the admissions procedure would have been held valid. ${ }^{78}$

No relief froin the ambiguities of Reed was provided by the Supreme Court's most recent consideration of a classification which disadvantaged women. In Frontiero v. Richardson, ${ }^{79}$ the Court invalidated a statute ${ }^{80}$ which allowed a male member of the armed forces to claim his wife as a dependent without regard to whether she was in fact dependent upon him, while requiring a woman claimant to show that her husband was truly dependent. Although eight Justices agreed that the statute violated the equal protection standard embodied in the fifth amendinent, no theory of review commanded inore than a plurality. ${ }^{81}$ Four members of the Court held that classifications based on sex were suspect and found "at least implicit support for such an approach in our unamimous decision only last term in Reed v. Reed . . .".82 Two concurring opinions purported to apply the rational basis test as utilized in Reed and argued that under that standard the statute worked an invidious discrimination. ${ }^{83}$

77. See Opening Brief for Appellants at 56-58, Berkelman v. San Francisco Unified School Dist., 501 F.2d 1264 (9th Cir. 1974). The school also failed to prove another point: "No actual proof that a balance of the sexes furthers the goal of better academic education was offered by the school district." 501 F.2d 1264, 1269 (9th Cir. 1974).

78. Applying the rationality scrutiny test means that if the challenged classification is factually related to a valid state objective, it will be sustained. See Gunther 21.

79. 411 U.S. 677 (1973).

80. 37 U.S.C. $\$ \$ 401,403$ (1970); 10 U.S.C. $\S \S 1072,1076$ (1970). Since this was a federal statute, the decision was based on the due process clause of the fifth amendment. See note 1 supra.

81. Justice Brennan announced the judgment and delivered a plurahty opinion, in which Justices Douglas, White, and Marshall joined. Justice Stewart filed a concurring opinion, and Justice Powell, joined by Justices Burger and Blackmun, filed another concurring opinion. Justice Rehnquist dissented, without writing an opinion.

82. 411 U.S. at 682.

83. Justice Stewart simply stated that the statutes worked an invidious discrimination, citing Reed. 411 U.S. at 691. Justice Powell wanted to decide Frontiero on the basis of Reed without resort to making sex a suspect classification. Interestingly, he also declined to make sex a suspect catcgory because of the pending ratification of the Equal Rights Ainendment. Id. at 692. This amendment, H.R.J. Res. 208, 92d Cong., 1st Sess. (1971); S.J. Res. 8, 92d Cong., 1st Sess. (1971), states:

Section 1. Equality of rights under the law shall not be denied or abridged by the United States or by any State on account of sex.

Section 2. The Congress shall have the power to enforce, by appropriate legislation, the provisions of the article.

Section 3. This amendment shall take effect two years after the date of ratification. 
Hence, the present status of sex-based classifications under the equal protection clause is in a state of uncertainty. ${ }^{84}$ While it is generally believed that the Muller-Goesaert-Hoyt rationale is no longer fully applicable, there is the widest possible disagreement as to which standard to use in its place. Unfortunately, no Supreme Court case subsequent to Frontiero has directly addressed the question of the appropriate treatment under the equal protection clause of classifications which disadvantage women. ${ }^{85}$

\section{STRICT SCRUTINY IN Reed}

Close examination of Reed indicates that instead of applying any rationality scrutiny type of review, or even the rational basis test, the Court actually applied a suspect classification method of analysis, albeit sub rosa. ${ }^{86}$ This interpretation is the only adequate explanation of why the statute was labeled "arbitrary" despite the fact that both the traditional rational relation test and the new rationality scrutimy test would lave been satisfied. ${ }^{87}$ Furthermore, the opinion strongly sug-

For a discussion of this amendment, see Brown, Emerson, Falk \& Freedman, The Equal Rights Amendment: A Constitutional Basis for Equal Rights for Women, 80 YALE L.J. 871 (1971).

84. Compare Miskunas v. Union Carbide Corp., 399 F.2d 847 (7th Cir. 1968), cert. denied, 393 U.S. 1066 (1969), and Stanton v. Stanton, 30 Utah 2d 315, 517 P.2d 1010 (1974), where the courts apphed the traditional rational basis test to sex-based classifications and sustained them, with Karczewski v. Baltimore \& O.R.R., 274 F. Supp. 169 (N.D. Ill. 1967), and Commonwealth v. Daniel, 430 Pa. 642, 243 A.2d 400 (1968), where the courts purported to apply the traditional test, but invalidated statutes which discriminated on the basis of sex. Another variation is exemplified by Sail'er Inn, Inc. v. Kirby, 5 Cal. 3d 1, 485 P.2d 529, 95 Cal. Rptr. 329 (1971), where the strict scrutiny standard was applied. Yet another approach is seen in Berkelman v. San Francisco Unified School Dist., 501 F.2d 1264 (9th Cir. 1974), where the court applied the interntediate test of rationality scrutiny.

85. Two other recent Supreme Court cases have addressed the sex-discrimination issue, at least tangentially, but neither of them is directly on point. Cleveland Bd. of Educ. v. LaFleur, 414 U.S. 632 (1974), involved a suit by two pregnant public school teachers who challenged mandatory unpaid leave rules. However, the holding which struck down these regulations was based on due process rather than equal protection. Geduldig v. Aiello, 417 U.S. 484 (1974), held that where California's disability insurance program exempted from coverage any work loss due to normal pregnancy, there was no denial of equal protection. However, in the Court's view, this program did not discriminate on the basis of sex since, "There was no risk from whicl men are protected and women are not." Id. at 496-97 n.20. Because the cases concerning pregnancies are not simply sex-discrimmation cases, but involve something nore, this Note will not discuss them in depth.

86. See Frontiero v. Richardson, 411 U.S. 677, 682-88 (1973) (plurahty opinion); Brenden v. Independent School Dist., 477 F.2d 1292, 1296 (8th Cir. 1973); cf. Getman, supra note 19, at 164-65 ("It seems likely that Reed and Stanley are the forerunners of a policy of strict review in cases involving discrimination on the basis of sex."); Gunther 34.

87. See text accompanying notes 58-61 supra. 
gests the apphicability in sex discrimination cases of the "compelling interest" and "less restrictive alternative" aspects of the stricter level of review. Despite their legitimacy as legislative goals, ${ }^{88}$ administrative efficiency and the reduction of familial strife were not sufficient to justify the statute in Reed. The Court's language also permits the conclusion that it would have upheld a statute which furthered these "positive values" by a means less restrictive of rights which the Court considered important. ${ }^{80}$ Significantly, these factors are the same as those that are taken into account in determining the constitutionality of a suspect classification, such as race, under the equal protection clause. ${ }^{90}$

Furthermore, an examination of the policies giving rise to the theory of suspect classifications will show the desirability of including sexual classifications in this group. ${ }^{.1}$ This doctrine requires that a discrete group in society should not be singled out for invidious treatment merely on the basis of traditional, stereotyped notions. ${ }^{92}$ Politically impotent, these groups are generally characterized by features with which they were born and which they cannot change..$^{93}$ Prejudice concerning these groups becomes enbodied in legislation, often not because of the desire to achieve a proper governmental objective, but because of popular behiefs as to the inferiority and "differentness" of the members of the groups. ${ }^{94}$ This model applies to the position of women exactly,

88. See 404 U.S. at 76: "Clearly the objective of reducing the workload on probate courts by eliminating one class of contests is not without some legitimacy. The crucial question, however, is whether ... [this statute] advances that objective in a manner consistent with the cominand of the Equal Protection Clause. We hold that it does not."

89. See note 88 supra.

90. See Getman, supra note 19 , at 162 .

91. For a discussion of the policy arguments behind suspect classifications, see Note, Ameliorative Racial Classifications Under the Equal Protection Clause: DeFunis v. Odegaard, 1973 Duke L.J. 1126, 1147; Equal Protection Developments 1107; Comment, Are Sex-Based Classifications Constitutionally Suspect?, 66 Nw. U.L. REv. 481, 496 (1971).

92. See United States v. Carolene Products Co., 304 U.S. 144, 152-53 n.4 (1938): "[P]rejudice against discrete and insular minorities may be a special condition, which tends seriously to curtail the operation of those political processes ordinarily to be relied upon to protect minorities, and which inay call for a correspondingly more searching judicial inquiry."

93. See Frontiero v. Richardson, 411 U.S. 677, 686 (1973):

Morcover, since sex, like race and national origin, is an immutable characteristic determined solely by the aecident of birth, the imposition of special disabilities upon the members of a particular sex because of their sex would seem to violate "the basic concept of our system that legal burdens should bear soine relationship to individual responsibility . . . " Weber v. Aetna Cas. \& Sur. Co., 406 U.S. 164, 175 (1972).

94. For a discussion of the stigma of inferiority attached to such groups, see Sail'er Inn, Inc. v. Kirby, 5 Cal. 3d 1, 19, 95 Cal. Rptr. 329, 340-41, 485 P.2d 529, 540-41 (1971). 
as it is indeed true that they have been a politically powerless group, singled out for a legislative treatment which in effect keeps them in an inferior status and is often based on traditional notions of sexual roles and capabilities. ${ }^{95}$ Because of the strong policy reasons for applying the highest standard of review in sex discrimination cases, it is inappropriate either to continue the automatic validation of discriminatory statutes under the minimal rationality test or to subject this area of the law to the vagaries of the rationality scrutiny test with its heavy emphasis upon the fact-gathering abilities of counsel.

\section{Ameliorative SeX-Based Classifications}

Immediately upon this conclusion, however, one is faced with the problein of ameliorative sex-based classifications-those which attempt to alleviate the effects of past discrimination. ${ }^{96}$ Should such classifications be treated in the same manner as those which disadvantage women, or are they to be scrutinized under a less rigorous standard?

Two recent Supreme Court cases have attenpted to deal with this question: Kahn v. Shevin ${ }^{97}$ and Schlesinger v. Ballard. ${ }^{98}$ In Kahn, a Florida statute giving widows a $\$ 500$ exemption from the property tax while denying the same exemption to widowers was sustained against an equal protection attack. The Court used the traditional language of the rational basis test in stating that the statute was "reasonably designed to further the state policy of cushioning the financial impact of spousal loss upon the sex for whoin that loss imposes a disproportionately heavy burden." scrutimy requirement that a classification must have a "fair and substantial relation to the object of the legislation." 100 In a footnote the

95. See Johnston \& Knapp, supra note 33, at 738-40.

96. It should be clearly understood that an ameliorative classification is not simply one that is favorable towards women. Rather, it is one which improves women's position, and in this context, it is one which alleviates the effects of past discrimination. Webster's ThiRd NEW INTERnational Dictionary (1961) defines ameliorate as "to make better: improve." The opinion in Kahn v. Shevin, 416 U.S. 351 (1974), seemed to recognize this definition when it said:

And in Frontiero the plurality opinion also noted that the statutes there were

"not in any sense designed to rectify the effects of past discrimination against

women. On the contrary, these statutes seize upon a group-women-who have historically suffered discrimination in employment, and rely on the effects of this past discrimination as a justification for heaping on additional econoinic disadvantages." Id. at $355 \mathrm{n} .8$ (citation ormitted).

97. 416 U.S. 351 (1974). It is interesting to note that Justice Douglas, who wrote the opinion in Kahn, agreed with the plurality in Frontiero that sex was a suspect classification. See 411 U.S. at 682-88.

98. 43 U.S.L.W. 4158 (U.S. Jan. 15, 1975).

99. 416 U.S. at 355.

100. Id., citing Reed v. Reed, 404 U.S. 71, 76 (1971), quoting Royster Guano Co. v. Virginia, 253 U.S. 412,415 (1920). 
Court rejected the contention that a better means of achieving this goal should be required, thus explicitly refusing to apply the less restrictive alternative requirement of the strict scrutiny test. ${ }^{101}$

$K a h n$, then, rejected the proposition that amehorative classifications based on sex are unconstitutional under the strict scrutiny standard in that they are not based on a coinpelling state interest, a viewpoint urged by the dissenters in that case. ${ }^{102}$ Neither did Kahn decide that such classifications, although subject to strict scrutiny, are justified by a compelling state interest. The highest level of equal protection review was simply not apphied at all. Furthermore, it is evident that the new rationality scrutiny test was not used. The Court made no atteinpt to determine the efficacy of the exemption in achieving the desired objective of equalizing the financial positions of widows and widowers, nor was the state required to cone forward with evidence on this point.

However, Kahn should not be taken as having restored the minimal scrutiny standard for all sex-based classifications. In endorsing the statute's purpose of cushioning the financial impact of spousal loss only for widows, the Court recognized that women generally have not earned as much money as men and that such differences in income have frequently resulted from sex discrimination. ${ }^{103}$ Frontiero was distinguished explicitly on this basis. In Frontiero, the classification was "solely for adımimistrative convenience"104 whereas in Kahn the distinction was imposed for the purpose of aiding widows in their financial plight, due in part to past discrimination. The clear implication is that the rational basis standard is appropriate for reviewing those sex-based

101. Id. at 356 n.10. Indeed, if the Court had applied this requirement, it is clear that it would not have been met, for lack of a showing either that all widows are more impecunious than all widowers or that all widows who pay property taxes are in financial need. A more narrowly drawn statute would have been necessary to reacli only those widows who were financially disadvantaged.

102. In one dissenting opinion, Justices Brennan and Marsliall claimed: "The statute nevertheless fails to satisfy the requirements of equal protection, since the State has not borne its burden of proving that its compelling interest could not be achieved by a nnore precisely tailored statute or by use of feasible less drastic means." Id. at 360 (Brennan \& Marsliall, JJ., dissenting). Justice White also dissented: "There is merit in giving poor widows a tax break, but gender-based classifications are suspect and require more justification than the State has offered." Id. at 361 (White, J., dissenting).

103. There can be no dispute that the financial difficulties confronting the lone woman in Florida or in any other state exceed those facing the man. Whether from overt discrimination or from the socialization process of a male dominated culture, the job market is inhospitable to the woman seeking any but the lowest paid job ..... D. D]ata compiled by the Women's Bureau of the United States Department of Labor shows that in 1972 a woman working full time had a inedian income which was only $57.9 \%$ of the median for males ..... Id. at 353.

104. Id. at 355 . 
classifications which alleviate the effects of past invidious discrimination.

In its most recent decision in this area, the Court reaffirmed the appropriateness of permissive review for ameliorative classifications. Schlesinger v. Ballard ${ }^{105}$ sustained the constitutionality of federal legislation $^{108}$ which granted tenure preferences to female naval officers. ${ }^{107}$ Using the equal protection standard inherent in the due process clause of the fifth amendment, ${ }^{108}$ the Court held that the statute was a permissible means of providing woinen an equitable program of advancement in the Navy. The Court's rationale rehed heavily upon the fact that naval personnel practices offered women less favorable opportunities to compile inpressive service records. ${ }^{109}$ Since the legislative classification furthered the ameliorative purpose of compensating feinale officers for this unequal treatinent, it fell squarely within the ambit of Kahn.110

\section{The Kahn Principle In the Lower Courts}

Two cases subsequent to Kahn, but prior to Ballard, have sustained the constitutionality of ameliorative classifications, and each subscribed to the foregoing view of the Kahn rationale. Kohr v. Weinberger ${ }^{111}$ sustained the benefits computation formula of the Social Security Act, ${ }^{112}$ which permits women to use fewer years than similarly situated men to compute their "average monthly wage" from which monthly benefits are determined, thus eliminating inore years of lower

105. 43 U.S.L.W. 4158 (U.S. Jan. 15, 1975).

106. 10 U.S.C. $\$ 6401$ (1970).

107. 43 U.S.L.W. at 4161.

108. See note 1 supra.

109. Id. at 4161 . The Court reasoned that since "male and female line officers in the Navy are not similarly situated with respect to opportunities for professional service . . . female heutenants will not generally have compiled records of seagoing service comparable to those of male heutenants." Id.

110. The Court, however, also chose to justify its opinion on the basis that different treatment of male and female officers was necessary in order for the Navy to attract and motivate qualified female officers. Id. at 4162 .

111. 378 F. Supp. 1299 (E.D. Pa. 1974).

112. 42 U.S.C. $\$ 415$ (b) (3) (1970):

(3) For purposes of paragraph (2), the number of an individual's elapsed years is the number of calendar years after 1950 (or, if later, the year in which he attained age 21) and before-

(A) in the case of a woman, the year in which she died or, if it occurred earlier but after 1960, the year in which she attained age 62 ,

(B) in the case of a man who has died, the year in which he died, or if it occurred earlier but after 1960, the year in whicls he attained age 65 , or

(C) in the case of a mau who has not died, the year occurring after 1960 in which he attained (or would attain) age 65. 
earnings than are eliminated for men. The court reached its conclusion by applying the permissive rational basis test. Although the reasons for selecting that test were not explicitly set forth in the opinion, the court recognized that a distinction should be made between statutes which rectify the effects of past discrimination and those which invidiously discriminate, and interpreted Kahn as standing for this proposition. ${ }^{113}$ Its holding is phrased both in terms of the ameliorative principle and the rational basis test.

[W] are satisfied that ... [the statute] is well within the constitutional limits set in ... [Reed and $\mathrm{Kahn}$ ] in that the statutory classification is reasonable and not arbitrary, and has a fair and substantial relationship to the object of the legislation because its effect is to rectify the economic effects of past discrimination against women. ${ }^{114}$

Another successor case to Kahn is People v. Elliot, ${ }^{115}$ where the Colorado Supreme Court held that a criminal statute iniposing the obligation for child support solely on the father did not violate the equal protection clause. In applying the rational basis test, the court relied upon the fact that men's economic advantages made thein generally better able than women to cope with the burden of child support. As in $K a h n$, the exemption of women from a pecuniary obligation was justified by the continuing effects of unequal opportumities in the economic area.

The proposition that men generally are more economically favored and, therefore, better able to support their children, is not entirely an obsolete concept. In April of this year the United States Supreme Court gave judicial notice to this view in sustaining a five hundred dollar property tax exemption to widows but not to widowers, in Kahn v. Shevin ....116

113. See 378 F. Supp. at 1303-04. At one point in the opinion, the court discussed Reed and Fronticro and cited them for the view that the Supreme Court is adopting a stricter standard for sex discrimination cases. Id. at 1303. At another point, the court spoke in terms of justifying the statute by a "coinpelling governmental interest." Id. The court finally decided to apply the rational basis test, relying upon, inter alia, the $K a h n$ holding as applicable precedent. Id. at 1304.

114. Id. The constitutionality of the same section of the Social Security Act was considered in Gruenwald v. Gardner, 390 F.2d 591 (2d Cir.), cert. denied, 393 U.S. 982 (1968). There the court decided, using reasoning similar to that used in Kohr although the case was considered before Kahn or Reed had been handed down, that the reduction of economic disparities between men and women justified sustaining the statute. But see Note, Sex Classifications in the Social Security Benefit Structure, 49 IND. L.J. 181, 183-84 (1973), which suggested that the early retirement scheme is simply a reflection of the societal view that women are not the primary wage earners.

115. 525 P.2d 457 (Colo. 1974).

116. $I d$. at 460 . 
It is therefore clear that Kahn, Ballard, and the subsequent lower court decisions ${ }^{117}$ show a judicial willingness to exempt ameliorative classifications from the sub rosa strict scrutiny test of Reed. This exemption is well founded simce the policy reasons for imposing a strict standard of review ${ }^{118}$ simply do not apply when the distinction based on sex alleviates the effects of past discrimination. ${ }^{119}$ Strict scrutiny of classifications which disadvantage women is appropriate because of women's traditionally inferior political and economic status, which in turn derives froin stereotyped ideas concerning their capabilities. In contrast, the very purpose of ameliorative classifications is to help remove the effects of such stereotyped treatinent. These classifications are designed to place women in the position which they would have occupied but for the past discrimination. ${ }^{120}$ Requiring strict scrutiny in such cases would be self-defeating, since the effect would be to aid in perpetuating the only sex-related status which satisfies the policy reasons for strict review. A similar policy analysis will show that $K a h n$ and its successors have properly used the rational basis test in judging the constitutionality of ameliorative classifications. No other test would be consistent with the basic principle of the equal protection clauseto treat those who are similarly situated in a similar manner. ${ }^{121} \mathrm{Be}-$ cause of the continuing effects of sexual bias, men and women are not similarly situated. Since an ameliorative classification treats men differently from women only in order to overcome the barriers of past discrimination so that they can become similarly situated with men, it serves to further the aim of equal protection. For this reason, the ouly

117. See Murphy v. Murphy, 232 Ga. 352, 206 S.E.2d 458 (1974), petition for cert. filed, 43 U.S.L.W. 3216 (U.S. Sept. 9, 1974) (No. 74255), which upheld a Georgia divorce statute authorizing alimony and attorneys' fee awards only to wives as reasonably designed to further the state policy of cushioning the financial impact of spousal loss upon the sex for whom that loss imposes the disporportionately heavy burden.

118. See notes 91-95 supra and accompanying text.

119. See Ginsburg, Toward Elimination of Sex-Based Discrimination: Constitutional Aspects, in Association of American Law Schools, Symposium on the Law SCHOOl. CURRICULUM AND tHe Legal Rights of WOMEN 29-30 (Part I 1972); cf. Ely, The Constitutionality of Reverse Racial Discrimination, 41 U. CHI. L. REv. 723 (1974). Ely's thesis is that certain classifications based on race which favor Blacks are eonstitutional and are to be judged under a lenient standard of review: "Rather than asserting that the demands of 'special scrutiny' can be met ... I shall suggest that 'special scrutiny' is not appropriate when White people have decided to favor Black people at the expense of White people." Id. at 727. Ely's reasoning is based on the idea that the policy arguments for labeling a criterion such as race to be suspect do not apply in the reverse case.

120. This characteristic is implicit in the definition of an ameliorative classification. See note 96 supra.

121. See note 92 supra and accompanying text. 
relevant inquiry is whether a challenged classification is reasonably related to its ameliorative purpose. Invidious sex-based classifications cannot rely on this rationale and are therefore subject to a stricter standard.

\section{The Impact of the Bifurcated Test}

Once it has been determined that the new bifurcated standard is the appropriate one for sex-based classifications, the remaining question is the effect which explicit recognition of the new test should have in those areas where distinctions on the basis of sex are inost commonly drawn.

\section{Employment}

Discriminatory employment practices have been the focus of much attention. Those which are the result of governmental action must be justified in terms of equal protection standards. ${ }^{122}$ Under the proposed test, most of the practices currently described as "female protective laws"123 would be unconstitutional. These laws typically provide for maximum hours of labor, minimum wages, and restrictions on working conditions under which women may be employed. Such regulations generally disadvantage women by restricting their employment opportunities and cannot be said to have as their aim the elimination of past discriminatory effects. Hence, they would receive strict scrutiny under the equal protection clause. Few of these statutes would meet such a standard. Although the protection of women from extremely taxing physical work might possibly be a compelling interest, these "protective" statutes are seldom so narrowly drawn. ${ }^{124}$

The most controversial issue in this field is the use of affirmative action programs which remedy employment discrimination by giving preferred treatment to women in the hiring, transfer, and promotion processes. ${ }^{125}$ Since those contracting with the government are encouraged by executive order ${ }^{126}$ to implement such programs in order to

122. See note 1 supra.

123. See note 26 supra.

124. See Dorsen \& Ross, The Necessity of a Constitutional Amendment, 6 HARv. CIv. RighTS-CIv. LIB. L. Rev. 216, 222-23 (1971).

125. These preferences include hiring goals for women employees akin to quotas, extensive recruitment efforts, and the promotion or transfer of women at a more favorable rate than men. See, e.g., Patterson v. American Tobacco Co., 43 U.S.L.W. 2160 (E.D. Va. Sept. 25, 1974); cf. Legal Aid Soc'y v. Brennan, 43 U.S.L.W. 2019 (N.D. Cal. June 20, 1974).

126. Exec. Order No. 11246, $\S 202(1), 3$ C.F.R. 169, 170 (1974), states: 
ensure that there are no discriminatory employment practices, affirmative action programs will become increasingly common. The recent case of Patterson v. American Tobacco Co ${ }^{127}$ presented a challenge to an affirmative action program in which the employer, in order to rennedy past discrimination im pay, job classifications, and promotions, gave priority to black and female employees over white male employees having less seniority but higher job classifications. Although the action was brought under Title VII, the court's discussion of the program's ameliorative character would be equally valid in an equal protection analysis: "The relief is warranted, however, where past discrimination has allowed those persons greater job opportunity than more senior blacks and females." ${ }^{28}$ Therefore, the court sustained the program. Patterson exemplifies the proper treatment under the bifurcated test for affirmative programs designed to eliminate discrimination. Clearly these programs are ameliorative; thus, they would be subject to the rational basis test and would be sustamed as long as they arguably worked to alleviate past effects of discrimination. However, this analysis would not permit unlimited favoritism of women employees. Presumably, a level could be reached where the preferences could not be justified in terms of removing past discriminatory effects. Such classifications would fail for lack of a reasonable relationship to the purpose of amelioration.

\section{Selective Service}

Another highly publicized issue is how women's exemption from the draft should be treated. Although personnel are not now being drafted, the draft, along with the equal protection problem, may be resurrected at some future time. Clearly this exemption benefits women. Furthermore, all decisions which have dealt with this situation under the equal protection clause ${ }^{129}$ have sustained the Selective

The contractor will not discriminate against any employee or applicant for employment because of race, color, religion, sex, or national origin. The contractor will take affirmative action to ensure that applicants are employed, and that employees are treated during employment, without regard to their race, color, religion, sex or national origin. Such action shall include, but not be limited to the following: employment, upgrading, demotion, or transfer; recruitment or recruitment advertising; layoff or termination; rates of pay or other forms of compensation; and selection for training, including apprenticeship.

Cf. 29 C.F.R. \$ 1607.14 (1974).

127. 43 U.S.L.W. 2160 (E.D. Va. Sept. 25, 1974).

128. Id. at 2161.

129. See United States v. Dorris, 319 F. Supp. 1306 (W.D. Pa. 1970); United States v. Cook, 311 F. Supp. 618 (W.D. Pa. 1970); United States v. Clinton, 310 F. Supp. 
Service Act. ${ }^{130}$ A typical example of the judicial reasoning on this point is United States v. St. Clair ${ }^{131}$ where the court inaintained: "In providing for involuntary service for men and voluntary service for women, Congress followed the teachings of history that if a nation is to survive, men must provide the first line of defense while wornen keep the home fires burning." 132 However, under the proposed test, a different decision would be required. Since the statute does not tend to eliminate the effects of past discrimination, it is not ameliorative; hence, an application of strict scrutiny is necessary. It is clear that the draft mecharnsm does not satisfy the less restrictive alternative requirement of the strict scrutiny standard, since the classification is both underinclusive and overinclusive. Men who have familial responsibilities are not included in the exemption whereas women who do not have such responsibilities are nevertheless exempted. A nore narrowly drawn statute would allow both men and wornen who wish to obtain an exemption on the ground of maintaining an orderly domestic life to apply for such an exemption and to have the merits of their claims evaluated. Furthermore, most military personnel today are not in coinbat positions, and warfare is becoming increasingly technological. Because of the resulting decrease in the importance of physical strength in the inodern military, it is doubtful that a compelling state interest for the draft exemption could be found. ${ }^{133}$

\section{CONCLUSION}

The proposed test for sex-based classifications has as its basic rationale the elimination of any invidious discrimination based on sex, whether this discrimination is caused by ongoing practices or is simply the effect of past practices. In order to implement this policy, the test

333 (E.D. La. 1970); Suskin v. Nixon, 304 F. Supp. 71 (N.D. Ill. 1969); United States v. St. Clair, 291 F. Supp. 122 (S.D.N.Y. 1968).

130. 5 U.S.C. App. $\$ \$ 451$ et seq. (1970).

131. 291 F. Supp. 122 (S.D.N.Y. 1968).

132. Id. at 125 .

133. In 1948, General Eisenhower stated:

Like most old soldiers I was violently against wonien soldiers. I thought a tremendous number of difficulties would occur, not only of an administrative nature ... but others of a more personal type that would get us into trouble. None of that occurred . .... In the disciplinary field they were . . . a model for the Army. More than this their influence throughout the entire command was good. I an convinced that in another war they have got to be drafted just like the nien. Ginsburg, supra note 120, at 20, quoting Hearings on S. 1614 Before the Subcomm. on Organization and Mobilization of the House Comm. on Armed Services, 80th Cong., 2d Sess. 5563-64 (1948).

See also Hale \& Kanowitz, Women and the Draft: A Response to Critics of the Equal Rights Amendment, 23 Hastings L.J. 199 (1971). 
stipulates two levels of review-strict scrutiny for purely discriminatory classifications and permissive review for ameliorative classifications. Under this standard, discrimination which has no useful purpose is discouraged while discrimination which contributes to the equality of the sexes is allowed, a result which could not be as effectively reached by one level of review for all sex-based classifications. 